\title{
VANADIUM PHOSPHATE SUPPORTED CATALYSTS FOR ETHANE OXIDATIVE DEHYDROGENATION
}

\author{
PAOLO CIAMBELLI ${ }^{\mathrm{a}}$, LUCIANA LISI $^{\mathrm{b}}$, GIOVANNA RUOPPOLO ${ }^{\mathrm{c}}$, \\ PASQUALE PATRONO ${ }^{\mathrm{d}}$, PAOLA GALLI ${ }^{\mathrm{e}}$, RAFFAELE PIRONE ${ }^{\mathrm{b}}$ and \\ GENNARO RUSSO ${ }^{c}$.
}

${ }^{a}$ Dipartimento di Ingegneria Chimica e Alimentare, Università di Salerno, (84084) Fisciano (SA), Italy.

${ }^{b}$ Istituto di Ricerche sulla Combustione, CNR, Napoli, Italy.

'Dipartimento di Ingegneria Chimica, Università "Federico II", Napoli, Italy *

${ }^{\mathrm{d}}$ Istituto di Metodologie Avanzate Inorganiche, CNR, Monterotondo Scalo (Roma), Italy.

'Dipartimento di Chimica, Università "La Sapienza", Roma, Italy.

\begin{abstract}
TiO}_{2}$ and $\mathrm{Al}_{2} \mathrm{O}_{3}$ supported $\mathrm{VOPO}_{4}$ was studied as catalyst for the oxidative dehydrogenation of ethane in the temperature range $450-550^{\circ} \mathrm{C}$. The catalytic performances were dramatically enhanced with respect to bulk $\mathrm{VOPO}_{4}$ as result of modified redox properties. Catalytic activity and selectivity to ethylene are associated to the presence of reduced vanadium, whose formation occurs during the reaction and is favoured by high temperature.
\end{abstract}

\section{INTRODUCTION}

Oxidative dehydrogenation (ODH) of light hydrocarbons is a potential alternative to dehydrogenation process for olefins industrial production ${ }^{1}$. Vanadium oxide based catalysts investigated for the $\mathrm{ODH}$ of ethane, propane and butane showed high activity but poor selectivity ${ }^{1,2}$, while quite a good selectivity but low activity has been reported for bulk and $\mathrm{TiO}_{2}$ supported $(\mathrm{VO})_{2} \mathrm{P}_{2} \mathrm{O}_{7}{ }^{3,4}$.

In this paper the catalytic performances of $\mathrm{VO}\left(\mathrm{PO}_{4}\right) \cdot 2 \mathrm{H}_{2} \mathrm{O}$ supported on $\mathrm{TiO}_{2}$ and $\gamma-\mathrm{Al}_{2} \mathrm{O}_{3}$ have been investigated for ethane $\mathrm{ODH}$. Catalytic activity and physico-chemical properties of bulk $\mathrm{VOPO}_{4} \cdot 2 \mathrm{H}_{2} \mathrm{O}$ were also investigated for comparison. 


\section{EXPERIMENTAL PROCEDURE}

Bulk vanadium phosphate, $\mathrm{VOPO}_{4} \cdot 2 \mathrm{H}_{2} \mathrm{O}$ (VOP), was prepared by refluxing $\mathrm{V}_{2} \mathrm{O}_{5}$ in $\mathrm{H}_{3} \mathrm{PO}_{4}(85 \%)$ and distilled water for 16 hours according to Ladwig method ${ }^{5}$. Three supported catalysts were prepared by contacting one anatase $\mathrm{TiO}_{2}$ sample $\left(125 \mathrm{~m}^{2} \mathrm{~g}^{-1}\right.$ surface area) and two $\gamma-\mathrm{Al}_{2} \mathrm{O}_{3}$ samples (100 and $190 \mathrm{~m}^{2} \mathrm{~g}^{-1}$ surface area) with water solutions of VOP, drying at $80^{\circ} \mathrm{C}$ and calcining in flowing air at $550^{\circ} \mathrm{C}$ for 3 hours.

A Philips diffractometer PW 1100 was employed for X-ray diffraction (XRD) analysis. BET surface areas were measured by $\mathrm{N}_{2}$ adsorption at $77 \mathrm{~K}$ with a CHEMBET 300 Quantachrom instrument. Electron paramagnetic resonance (EPR) spectra were obtained with a Varian E-9 spectrometer equipped with a standard Oxford instrument low-temperature attachment. Temperature Programmed Reduction (TPR) with $\mathrm{H}_{2}$ and Temperature Programmed Desorption (TPD) of $\mathrm{NH}_{3}$ were carried out using a Micromeritics TPD/TPR 2900 analyser equipped with a TCD and coupled with a Hiden HPR 20 mass spectrometer. The samples were reduced by a $2 \% \mathrm{H}_{2} / \mathrm{Ar}$ mixture $\left(25 \mathrm{~cm}^{3}\right.$ $\left.\mathrm{min}^{-1}\right)$ in TPR or treated with flowing $\mathrm{He}\left(25 \mathrm{~cm}^{3} \mathrm{~min}^{-1}\right)$ heating $10^{\circ} \mathrm{C} \mathrm{min}^{-1}$ up to $650^{\circ} \mathrm{C}$ after ammonia adsorption in TPD experiments. Before either TPR and TPD experiments the samples were treated in flowing air at $550^{\circ} \mathrm{C}$ for 2 hours.

Catalytic activity tests were carried out with a fixed bed quartz microreactor. The reaction products were analysed by Hewlett Packard series II 5890 gas-chromatograph equipped with thermal conductivity and flame ionization detector for the analysis of $\mathrm{O}_{2}$, $\mathrm{CO}$ and $\mathrm{CO}_{2}$ and for that of hydrocarbons, respectively. The feed composition was $4 \%$ $\mathrm{C}_{2} \mathrm{H}_{6}$ and $2 \% \mathrm{O}_{2}$ in a balance of $\mathrm{He}$. The reaction temperature was 450 or $550^{\circ} \mathrm{C}$. The space time ranged from 0.006 to $0.12 \mathrm{~g} \mathrm{~s} \mathrm{Ncm}^{-3}$. Carbon balance was closed within $3 \%$ error in all experiments.

\section{RESULTS AND DISCUSSION}

The catalysts composition is reported in table 1 . On the basis of $\mathrm{VOPO}_{4}$ cell parameters ${ }^{6}$ the VOP content of VOP/Ti catalysts corresponds to sub-monolayer (VOP $7.0 \mathrm{wt} \%$ ) and monolayer (VOP $9.6 \mathrm{wt} \%$ ) coverage, while that of VOP/Al samples corresponds to monolayer (VOP $7.9 \mathrm{wt} \%$ ) and over-monolayer coverage (VOP $14 \mathrm{wt}$ 
$\%$ ) XRD spectra revealed only the signals of the supports denoting high surface dispersion of VOP, also shown by the surface areas very similar to those of the supports.

The EPR spectra indicate the presence of $\mathrm{V}^{4+}$ both in bulk and supported $\mathrm{VOPO}_{4}$. The axial simmetry and the good resolution of the signals suggest chemical equivalence and magnetic dilution of $\mathrm{V}^{4+}$. The magnetic parameters of the samples are almost superimposable to those reported ${ }^{6}$ for $\mathrm{VO}\left(\mathrm{H}_{2} \mathrm{O}\right)_{5}^{2+}$ ion, suggesting that $\mathrm{VO}^{2+}$ is sixcoordinated to lattice oxygens and water molecules of VOP. Furthermore, the formation of $\mathrm{VO}\left(\mathrm{H}_{2} \mathrm{O}\right)_{4}^{2+}-\mathrm{O}-\mathrm{P}$ species can be supposed if one compares the parameters values with those found ${ }^{7}$ for $1-2 \% \mathrm{~V}^{4+} / \mathrm{VOPO}_{4} \cdot 2 \mathrm{H}_{2} \mathrm{O}$.

All samples show a single TPR peak associated to vanadium reduction, while the supports do not undergo significant reduction. The peak temperature of the unsupported VOP is markedly reduced $\left(100-150^{\circ} \mathrm{C}\right.$ lower) in the VOP supported catalysts. Moreover, the hydrogen consumption, reported in table 1 in terms of $\mathrm{V} / \mathrm{H}_{2}$ ratio, shows that the extent of vanadium reduction of unsupported VOP is much lower than that of the supported ones, likely due to a limited diffusion of $\mathrm{H}_{2}$ through the particle bulk. Vanadium reducibility of VOP/Ti catalysts appears something higher than that of $\mathrm{VOP} / \mathrm{Al}$ samples. Finally, the $\mathrm{V} / \mathrm{H}_{2}$ values greater than 1 indicate the presence of $\mathrm{V}^{4+}$ in addition to $\mathrm{V}^{5+}$ in all samples, in agreement with EPR characterization.

TABLE 1 Composition and surface area of the catalysts and results of TPR and TPD experiments.

\begin{tabular}{lcccc}
\hline Catalyst & $\begin{array}{c}\text { VOP content } \\
(\text { wt } \%)\end{array}$ & $\begin{array}{c}\text { Surface Area } \\
\left(\mathrm{m}^{2} \mathrm{~g}^{-1}\right)\end{array}$ & $\begin{array}{l}\text { V/H } \\
\text { from TPR }\end{array}$ & $\begin{array}{c}\text { des. } \mathrm{NH}_{3} \text { from TPD } \\
\times 10^{6}\left(\mathrm{~mol} \mathrm{~m}^{-2}\right)\end{array}$ \\
\hline VOP & 100 & $<1$ & 4.0 & - \\
VOP/Ti-7 & 7.0 & 125 & 1.3 & 1.9 \\
VOP/Ti-9 & 9.6 & 125 & 1.4 & 2.3 \\
VOP/Al-7 & 7.9 & 101 & 1.6 & 1.5 \\
VOP/Al-14 & 14.0 & 162 & 1.7 & 3.2 \\
\hline
\end{tabular}

No desorption of $\mathrm{NH}_{3}$ was observed for the unsupported VOP. Bagnasco et al. ${ }^{8}$ reported a value of about $10^{-3}$ mol $\mathrm{NH}_{3}$ per gram of hydrated $\mathrm{VO}\left(\mathrm{PO}_{4}\right) \cdot 2 \mathrm{H}_{2} \mathrm{O}$ due to ammonia intercalation between the layers of phosphate. Therefore, the treatment at $550^{\circ} \mathrm{C}$ carried out for our samples should have resulted in hindered intercalation due to layered 
structure-collapse. For the supported catalysts, ammonia is desorbed in a wide range of temperatures $\left(100-600^{\circ} \mathrm{C}\right)$ due to the presence of different types of adsorbed species. However, it should be noticed that both supports have a strong surface acidity and, therefore, they could give a significant contribution to the TPD signal.

In the experimental conditions of the catalytic test $\mathrm{C}_{2} \mathrm{H}_{6}$ was only converted to $\mathrm{C}_{2} \mathrm{H}_{4}, \mathrm{CO}$ and $\mathrm{CO}_{2}$, the $\mathrm{O}_{2}$ conversion being always far from $100 \%$. The catalytic activity of both supports is negligible if compared to that of all supported catalysts. Unsupported VOP shows a very low catalytic activity $\left(\mathrm{C}_{2} \mathrm{H}_{6}\right.$ consumption rate at $550^{\circ} \mathrm{C}<10^{-8} \mathrm{~mol} \mathrm{~g}^{-1}$ $\mathrm{s}^{-1}$ ) with high selectivity to ethylene. The activity was dramatically enhanced (three orders of magnitude higher) by supporting VOP on titania or alumina. The effect of ethane conversion on ethylene selectivity is shown in figure 1. For all catalysts, by increasing the contact time the conversion of $\mathrm{C}_{2} \mathrm{H}_{6}$ and the selectivity to $\mathrm{CO}$ increase, the selectivity to $\mathrm{C}_{2} \mathrm{H}_{4}$ decreases, while that to $\mathrm{CO}_{2}$ is only slightly changed. This suggests that $\mathrm{CO}$ is produced by further oxidation of $\mathrm{C}_{2} \mathrm{H}_{4}$, while $\mathrm{CO}_{2}$ is mainly formed by ethane oxidation, as also found for $\mathrm{V}_{2} \mathrm{O}_{5} / \mathrm{TiO}_{2}$ catalysts either for ethane ${ }^{9}$ and for propane ${ }^{10}$ $\mathrm{ODH}$. In table 2 the rates of $\mathrm{C}_{2} \mathrm{H}_{6}$ consumption and $\mathrm{C}_{2} \mathrm{H}_{4}$ formation at $550^{\circ} \mathrm{C}$ are reported. With both catalytic systems all the rates increase with VOP content, the specific reaction rate of ethane per vanadium atom being mostly constant The VOP/Ti catalysts are more active and selective than the VOP/Al ones

For all catalysts both activity and selectivity to ethylene are enhanced by increasing the reaction temperature (figure 1), in contrast with the general behaviour of catalysts containing transition metal oxides, which at high temperature promote the oxidation of ethane to $\mathrm{COx}^{2}$. In order to elucidate the effect of temperature on the catalytic properties, further TPR experiments were carried out with VOP/Ti samples immediately after the catalytic test $\left(12 \mathrm{~h}\right.$ at either 450 or $\left.550^{\circ} \mathrm{C}\right)$ and without performing any thermal treatment before TPR measurement. The results reported in table 3 show that the $\mathrm{H}_{2}$ uptake of both VOP/Ti catalysts after reaction at $550^{\circ} \mathrm{C}$ is lower than that of the fresh sample, suggesting that the catalysts are reduced during the $\mathrm{ODH}$ reaction. When the reaction temperature was $450^{\circ} \mathrm{C}$ the oxidation state of vanadium was unchanged, indicating a marked effect of the temperature on the reduction process. All the samples were reoxidised by air treatment. Therefore, it can be assumed that vanadium phosphate is more active and is more active and selective at high temperature as result of vanadium 
reduction: As a further confirm of this interpretation a TPR experiment was carried out with VOP/Ti-9 after treating the sample in flowing ethane at $550^{\circ} \mathrm{C}$. The $\mathrm{H}_{2}$ uptake resulted lower than that consumed by the fresh catalyst but also that consumed by the catalyst after the $\mathrm{ODH}$ reaction at $550^{\circ} \mathrm{C}$, suggesting that ethane is able to reduce the catalyst during the reaction.

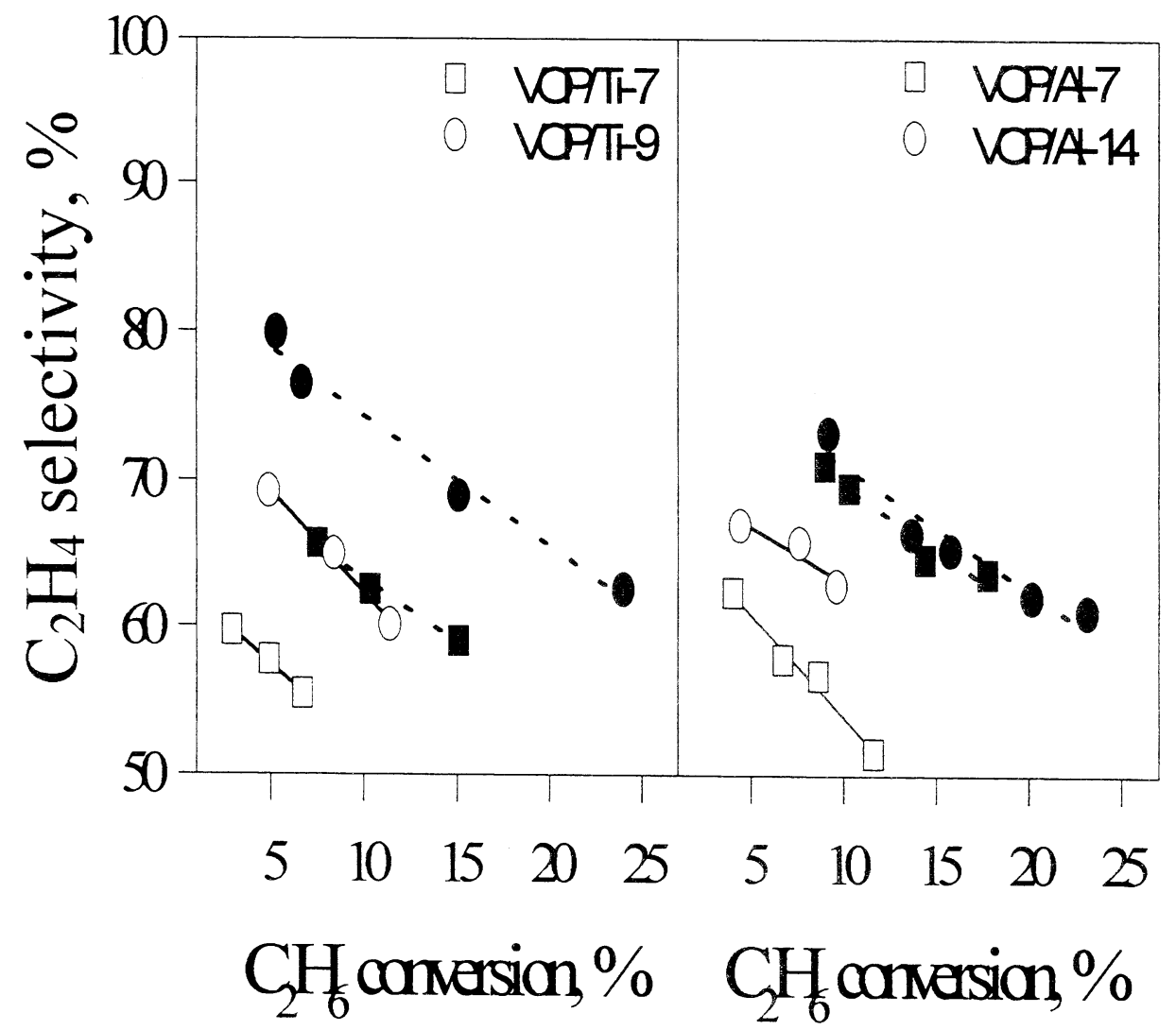

FIGURE 1. $\mathrm{C}_{2} \mathrm{H}_{4}$ selectivity as a function of $\mathrm{C}_{2} \mathrm{H}_{6}$ conversion for supported VOP catalysts at $450^{\circ} \mathrm{C}$ (open symbols) and $550^{\circ} \mathrm{C}$ (full symbols).

TABLE 2 Rate of ethane consumption and ethylene formation at $550^{\circ} \mathrm{C}$.

\begin{tabular}{ccccc}
\hline Catalyst & $\begin{array}{c}\mathrm{rC}_{2} \mathrm{H}_{6} \times 10^{6} \\
\left(\mathrm{~mol} \mathrm{~g}^{-1} \mathrm{~s}^{-1}\right)\end{array}$ & $\begin{array}{c}\mathrm{rC}_{2} \mathrm{H}_{4} \times 10^{6} \\
\left(\mathrm{~mol} \mathrm{~g}^{-1} \mathrm{~s}^{-1}\right)\end{array}$ & $\begin{array}{c}\mathrm{rC}_{2} \mathrm{H}_{6} \times 10^{2} \\
\left(\mathrm{~mol} \mathrm{molV}^{-1} \mathrm{~s}^{-1}\right)\end{array}$ & $\begin{array}{c}\mathrm{rC}_{2} \mathrm{H}_{4} \times 10^{2} \\
\left(\mathrm{~mol} \mathrm{molV}^{-1} \mathrm{~s}^{-1}\right)\end{array}$ \\
\hline VOP/Ti-7 & 11.2 & 7.0 & 2.6 & 1.6 \\
VOP/Ti-9 & 16.2 & 11.3 & 2.7 & 1.9 \\
VOP/Al-7 & 4.9 & 3.5 & 1.0 & 0.72 \\
VOP/Al-14 & 7.5 & 5.5 & 0.84 & 0.66 \\
\hline
\end{tabular}


TABLE $3 \quad \mathrm{H}_{2}$ uptake resulting from TPR experiments with used catalysts.

\begin{tabular}{cc}
\hline Catalyst & $\mathrm{H}_{2}$ uptake $\times 10^{4}\left(\mathrm{~mol} \cdot \mathrm{g}^{-1}\right)$ \\
\hline VOP/Ti-7 after reaction at $450^{\circ} \mathrm{C}$ & 3.2 \\
VOP/Ti-7 after reaction at $550^{\circ} \mathrm{C}$ & 2.5 \\
VOP/Ti-9 after reaction at $450^{\circ} \mathrm{C}$ & 4.3 \\
VOP/Ti-9 after reaction at $550^{\circ} \mathrm{C}$ & 3.2 \\
VOP/Ti-9 after $\mathrm{C}_{2} \mathrm{H}_{6}$ treatment at $550^{\circ} \mathrm{C}$ & 2.1 \\
\hline
\end{tabular}

SUMMARY Supported $\mathrm{VOPO}_{4}$ catalysts are active and selective in the oxidative dehydrogenation of ethane showing dramatically enhanced performances with respect to bulk $\mathrm{VOPO}_{4}$. The dispersion of $\mathrm{VOPO}_{4}$ on titania or alumina results in a significant modification of the vanadium redox properties. The higher reducibility of vanadium enhances both activity and selectivity to ethylene, the vanadium reduction being favoured at increased reaction temperature.

\section{REFERENCES}

1 F. Cavani, F. Trifirò, Catal. Today, 24, 307 (1995).

2 T. Blasco, J. M. López-Nieto, A. Dejoz, M. I. Vàsquez, J. Catal., 157, 271 (1995).

3 P. M. Michalakos, M. C. Kung, I. Jahan, H. H. Kung, J. Catal., 140, 226 (1993).

4 L. Savary, J. Saussey, G. Costentin, M. M. Betthar, M. Gubelmann-Bonneau, J. C. Lavalley, Catal. Today, $\underline{32}, 57$ (1996).

5 G. Ladwig, Z. Anorg. Chem., 338, 266 (1965).

6 D. Ballutaud, E. Bordes, P. Courtine., Mater.Res. Bull., 17, 519 (1982).

7 R.N. Rogers, G. E. Pake, J. Chem. Phys., 33, 1107 (1960).

8 G. Bagnasco, L. Benes, P. Galli, P. Patrono, M. Turco, V. Zima, J. Thermal Analysis, $\underline{52}, 615$ (1998).

9 P. Ciambelli, L. Lisi, G. Ruoppolo, G. Russo, J. C. Volta, Studies Surf. Sci. Catal., 110,287 (1997).

10 P. Ciambelli, L. Lisi, G. Ruoppolo, G. Russo, P. Viparelli, Appl. Catal. A., in press. 